\title{
Hereditary Alterations in the Immune Response: Coexistence of 'Agammaglobulinemia', Acquired Hypogammaglobulinemia and Selective Immunoglobulin Deficiency in a Sibship
}

\author{
Rebecca H. Buckley ${ }^{[75]}$ and J. B. Sidbury, Jr. \\ Departments of Pediatrics, Microbiology and Immunology, Division of Immunology, \\ Duke University School of Medicine, Durham, North Carolina, USA
}

Extract

A longitudinal immunologic study was conducted in a family in which an entire sibship of three males was unduly susceptible to infection. The oldest boy's history of repeated severe infections beginning in infancy and his marked deficiencies of all three major immunoglobulins were compatible with a clinical diagnosis of congenital 'agammaglobulinemia' (table I, fig. 1). Recurrent severe infections in the second boy did not begin until late childhood, and his serum abnormality involved deficiencies of only two of the major immunoglobulin fractions, IgG and IgM (table I, fig. 1). This phenotype of selective immunoglobulin deficiency is previously unreported. Serum concentrations of the three immunoglobulins in the youngest boy (who also had a late onset of repeated infection) were normal or elevated when he was first studied, but a marked decline in levels of each of these fractions was observed over a four-year period (table I, fig. 1). We could find no previous reports describing apparent congenital and acquired immunologic deficiencies in a sibship.

Repeated infections and demonstrated specific immunologic unresponsiveness preceded gross abnormalities in the total and fractional gamma globulin levels in both of the younger boys (tables II-IV). When the total immunoglobulin level in the second boy was $735 \mathrm{mg} / 100 \mathrm{ml}$, he failed to respond with a normal rise in titer after immunization with ' $A$ ' and ' $B$ ' blood group substances, diphtheria, tetanus, or Types I and II poliovaccines. When the total immunoglobulin level in the youngest boy was $1564 \mathrm{mg} / 100 \mathrm{ml}$, he had absent ' $\mathrm{B}$ ' and low ' $\mathrm{A}$ ' isohemagglutinins. Later studies showed that he failed to respond with a normal rise in titer after stimulation with ' $\mathrm{A}$ ' and ' $\mathrm{B}$ ' blood group substances, diphtheria, tetanus, typhoid, and Types I, II and III poliovaccines.

Similar studies in family members demonstrated a marked polyclonal IgA hyperglobulinemia and specific immunologic unresponsiveness to ' $\mathrm{B}$ ' substance in the mother (tables I and II). She also gave poor circulating antibody responses to immunization with diphtheria and poliovaccines. Two maternal aunts had high normal levels of IgA and low isohemagglutinin titers (table VII). We are unaware of other reports of specific immunologic unresponsiveness and/or antibody deficiency in the apparent heterozygote for what appears to be an X-linked immunologic deficiency. A male maternal first cousin also had a high normal level of $\operatorname{IgA}$, asthma, shortness of stature and repeated respiratory infections. These findings provide direct evidence for a genetic influence in some forms of acquired immunologic deficiency. 


\section{Speculation}

The heterogeneity of immunologic abnormality observed in this family is inconsistent with many of the current hypotheses of the genetic defects in immunologic deficiency. An afferent phase defect seems to offer the best explanation for a single genetic mechanism of immunologic deficiency in this family. The question of a possible contributory role of repeated bacterial infections in the apparent progression and heterogeneity of immunologic deficiency in the members of this sibship is raised.

\section{Introduction}

Although congenital 'agammaglobulinemia' has been shown to be an X-linked heritable disorder [31, 42], no genetic basis has been established in primary acquired hypogammaglobulinemia or in selective immunoglobulin deficiency states. A genetic influence is strongly implicated in acquired hypogammaglobulinemia by FUdenberg et al. [25], Wolf [67] and WolHEIM et al. [69, 70], who found familial immunologic abnormalities in a number of cases of acquired hypogammaglobulinemia. Charache et al. [14] and BurTON et al. [12] reported acquired hypogammaglobulinemia in brothers. The possible influence of environmental factors was raised by RoBBins et al. [55] who, in documenting acquired hypogammaglobulinemia in a five-year-old girl, proposed that repeated severe infections may be causally related to the induction of immunologic deficiency and cited data from animal experimentation supporting such a mechanism $[7,22,47]$.

The present report describes the clinical and immunologic findings in three brothers with three different types of immunoglobulin deficiency syndromes: apparent congenital 'agammaglobulinemia', acquired hypogammaglobulinemia and a previously undescribed type of selective immunoglobulin deficiency. In addition, the mother of these three boys had a marked polyclonal IgA hyperglobulinemia and a defect in specific immunologic responsiveness. These findings provide direct evidence for a genetic influence in the development of some forms of acquired immunologic deficiency.

\section{Case 1}

\section{Case Reports}

The first child of this family (G. B.) was born March 1, 1949. He developed pertussis in early infancy; for several years thereafter he had recurrent bronchitis. His tonsils and adenoids were removed when he was six years of age, after which time he had increasingly severe and frequent infections, usually involving the ears and lower respiratory tract. Four episodes of acute pneumonia occurred at seven, ten and eleven years of age. He contracted measles at the age of six years and chickenpox at the age of seven years; both were mild and uncomplicated. When the patient was seven years of age, the first serum sample was obtained for electrophoretic examination. It was reported to show low or absent gamma globulins, whereupon a series of gamma globulin injections were administered. After several years of such treatment, systemic reactions (chills and fever) followed each injection of gamma globulin. $\mathrm{He}$ was first seen at the Duke University Medical Center in July, 1963, at the age of $14 \%: 2$ years. $\mathrm{He}$ was small, thin and appeared to be chronically ill, with substernal retraction, flaring of the alae nasae, clubbing of the fingers, cyanosis and scarring of the tympanic membranes. There was an increase in the anteroposterior diameter of the chest, and dry, crepitant rales were heard over the entire right lung field. At that time, examination of the serum by immunoelectrophoresis revealed findings compatible with a diagnosis of 'agammaglobulinemia'(table I). In November, 1964, at the age of $15 \% / 12$ years, he developed fever and acute respiratory distress which led to his demise. At necropsy there was widespread bilateral bronchopneumonia. The thymus gland appeared morphologically normal and the bone marrow was hyperplastic.

\section{Case 2}

The second child of this family (K.B.) was also a male, born October 10, 1951, but unlike his brother he remained well during infancy and early childhood. Measles and chickenpox were clinically mild. At approximately five years of age he began to have occasional mild episodes of bronchitis. When he was 10 and 11 years of age, he had three episodes of acute pneumonia and four more in his 13 th and 14th years. A serum electrophoretic analysis at the age of 10 years reportedly showed no need for gamma globulin injections.

When he was first seen at the Duke University Medical Center in July, 1963, at the age of $11 \% 12$ years, physical measurements indicated a developmental age of only $91 / 2$ years. He had a sallow complexion and appeared chronically ill. The tympanic membranes were dull and the tonsils were of moderate size. He had a loose cough, clubbing of the fingers, increased anteroposterior diameter of the chest, a Harrison's groove and 
crepitant rales over the right lung field. On admission to the Clinical Research Unit for immunologic evaluation in July, 1965 (at the age of $13 \%$ years), chest $\mathrm{x}$-ray showed a pneumonic infiltrate and atelectasis of the right middle lobe; sinus films demonstrated bilateral antral and ethmoid sinus clouding. Absolute lymphocyte counts on two occasions were 2106 and $2592 / \mathrm{mm}^{3}$. At bronchoscopy, purulent material was seen in the right middle lobe bronchus. Gross hematuria was associated with pneumonia on two occasions. Total serum complement activity (determined by titration using a 50 percent hemolytic endpoint) was normal both times, suggesting that the hematuria was not a manifestation of acute glomerulonephritis. The results of the immunologic studies are summarized in tables $\mathrm{I}-\mathrm{VI}$.

In December, 1965, at age 14 years, following an episode of pneumonia, chronic therapy with tetracycline was instituted and gamma globulin injections discontinued. The frequency of acute infections was significantly reduced and a growth spurt was observed in the succeeding months. Reinstitution of gamma globulin therapy did not further decrease the incidence of infection.

In April, 1967, he was admitted for removal of the right middle and lower lobes, after bronchograms had revealed no other areas with bronchiectasis. Histopathologic examination of a hilar lymph node removed at surgery revealed no evidence of lymphoma. Following surgery, he was discharged on the previous schedule of tetracycline and physical therapy, and another growth spurt was observed in the following six-month period.

Case 3

The third child (R.B.), also male, was born February 13,1957 . He had a history of frequent but mild colds, occasional ear infections and summer hay fever since six years of age, but there was no history of pneumonia or other lower respiratory involvement. In contrast to his brothers, his exercise tolerance was normal. $\mathrm{He}$ had measles at two years of age without untoward incident. Serum electrophoresis, performed when the child was six years of age, was reported to be normal.

When he was first seen at the Duke University Medical Center in July, 1963, at the age of $6 \frac{1}{2}$ years, his developmental age was comparable to his chronological age. The lungs were clear; otitis media was present; the tonsils were noted to be vestigial, and lymph nodes were shotty. When seen again in January, 1965, at the age of 8 years, he still had a normal developmental age but the chest had an increase in anteroposterior diameter and coarse breath sounds were heard over the right lung field.

In July, 1965, at the age of $8 \frac{1}{2}$ years, he was ad- mitted to the Duke Clinical Research Unit for immunological studies. Absolute lymphocyte counts on three occasions were 2988, 2412 and $3720 / \mathrm{mm}^{3}$. Chest xrays showed a band-like area of density in the right middle lobe and an infiltrate in the retrocardiac space. Sinus films demonstrated cloudy maxillary sinuses. Bronchoscopy showed an edematous and inflamed right middle lobe bronchus and purulent material within, which cultured Hemophilus influenza. The results of the immunological studies are shown in tables I-VI.

In October, 1965, when the subject was $8 \% / 12$ years of age, splenic enlargement was noted. Weight age and chronological age were still comparable at that time but, significantly, his height age was a year behind. In July, 1966, x-rays showed atelectasis of the right middle and left lower lobes. Adenoidectomy was contemplated as a measure to reduce the frequency of otitis media, but under anesthesia no adenoidal tissue could be demonstrated. Like his older brother, he showed a better response to a regimen of continuous tetracycline therapy than to gamma globulin injections, and the addition of gamma globulin to the tetracycline therapy did not enhance the benefit.

\section{Family History}

The mother of the three boys had no history of severe infections, lung disease or liver disease. She had recurrent otitis externa and reported hay fever symptoms which occurred primarily in July, August and September. There were no other siblings, nor was there a

Table II. Isohemagglutinin titers ${ }^{1}$ in members of the immediate family before and after immunization with blood group substances

\begin{tabular}{|c|c|c|c|c|}
\hline \multirow{2}{*}{$\begin{array}{l}\text { Source of } \\
\text { serum, } \\
\text { blood type }\end{array}$} & \multicolumn{2}{|c|}{ Anti 'A' } & \multicolumn{2}{|c|}{ Anti ' $B$ ' } \\
\hline & Pre & Post & Pre & Post \\
\hline $\begin{array}{l}\text { R.B. } \\
0, \mathrm{Rh}^{+}\end{array}$ & 16 & 16 & 0 & 0 \\
\hline $\begin{array}{l}\text { K.B. } \\
0, \mathrm{Rh}^{+}\end{array}$ & 32 & 32 & 32 & 32 \\
\hline $\begin{array}{l}\text { M. B. } \\
\text { Mother } \\
0, \mathrm{Rh}+\end{array}$ & 64 & 1024 & 4 & 8 \\
\hline $\begin{array}{l}\text { F.B. } \\
\text { Father } \\
0, \mathrm{Rh}^{+}\end{array}$ & 64 & 1024 & 32 & 256 \\
\hline
\end{tabular}

${ }^{1}$ All titers expressed as the reciprocal of highest positive dilution. 
Hereditary alterations in the immune response : Coexistence of 'agammaglobulinemia'...

Table I. Immunoglobulin levels over a period of four years in the members of the immediate family

\begin{tabular}{|c|c|c|c|c|c|}
\hline Subject & Date & $\begin{array}{l}\text { Age } \\
\text { years }\end{array}$ & $\begin{array}{l}\mathrm{IgG} \\
\mathrm{mg} / 100 \mathrm{ml}\end{array}$ & $\begin{array}{l}\text { IgA } \\
\mathrm{mg} / 100 \mathrm{ml}\end{array}$ & $\begin{array}{l}\mathrm{IgM} \\
\mathrm{mg} / 100 \mathrm{ml}\end{array}$ \\
\hline G. B. & $7 / 63$ & $14^{4} / 12$ & $55^{1}$ & $0^{1}$ & $10^{1}$ \\
\hline K. B. & $\begin{array}{l}7 / 63 \\
6 / 65 \\
6 / 66 \\
3 / 67\end{array}$ & $\begin{array}{l}11^{9} / 12 \\
13^{8} / 12 \\
14^{8} / 12 \\
15^{5} / 12\end{array}$ & $\begin{array}{l}423^{1} \\
365^{1} \\
290^{1} \\
225^{1}\end{array}$ & $\begin{array}{l}253 \\
167 \\
117 \\
122\end{array}$ & $\begin{array}{l}59 \\
36 \\
18^{1} \\
25^{1}\end{array}$ \\
\hline R.B. & $\begin{array}{l}7 / 63 \\
6 / 65 \\
6 / 66 \\
3 / 67\end{array}$ & $\begin{array}{c}6^{5} / 12 \\
8^{4} / 12 \\
9^{4} / 12 \\
10\end{array}$ & $\begin{array}{l}760 \\
410^{1} \\
340^{1} \\
265^{1}\end{array}$ & $\begin{array}{r}690^{2} \\
67^{1} \\
59^{1} \\
53^{1}\end{array}$ & $\begin{array}{c}114^{2} \\
44 \\
12^{1} \\
12^{1}\end{array}$ \\
\hline $\begin{array}{l}\text { M. B. } \\
\text { Mother }\end{array}$ & $\begin{array}{l}7 / 63 \\
6 / 65 \\
6 / 66 \\
3 / 67\end{array}$ & $\begin{array}{l}39 \\
41 \\
42 \\
43\end{array}$ & $\begin{array}{r}1263 \\
1200 \\
950 \\
900\end{array}$ & $\begin{array}{r}896^{2} \\
1274^{2} \\
1000^{2} \\
1000^{2}\end{array}$ & $\begin{array}{l}33^{1} \\
30^{1} \\
42 \\
39\end{array}$ \\
\hline $\begin{array}{l}\text { F.B. } \\
\text { Father }\end{array}$ & $\begin{array}{l}7 / 63 \\
6 / 65 \\
6 / 66\end{array}$ & $\begin{array}{l}43 \\
45 \\
46\end{array}$ & $\begin{array}{l}690 \\
900 \\
870\end{array}$ & $\begin{array}{l}450 \\
315 \\
340\end{array}$ & $\begin{array}{l}71 \\
46 \\
64\end{array}$ \\
\hline
\end{tabular}

1 Value below normal for age in this laboratory.

${ }^{2}$ Value above normal for age in this laboratory.

For normal range, see fig. 1 .

Table III. Typhoid ' $\mathrm{O}$ ' and ' $\mathrm{H}$ ' agglutinin and diphtheria and tetanus hemagglutinin titers in members of the immediate family before and after stimulation

\begin{tabular}{|c|c|c|c|c|c|c|c|c|}
\hline \multirow{3}{*}{$\begin{array}{l}\text { Source of } \\
\text { serum }\end{array}$} & \multicolumn{8}{|c|}{ Reciprocal of agglutinin or hemagglutinin titers } \\
\hline & \multicolumn{2}{|c|}{ Typhoid 'O' } & \multicolumn{2}{|c|}{ Typhoid 'H' } & \multicolumn{2}{|c|}{ Diphtheria } & \multicolumn{2}{|c|}{ Tetanus } \\
\hline & Pre & Post & Pre & Post & Pre & Post & Pre & Post \\
\hline R.B. & 0 & 0 & 0 & 0 & 40 & 243 & 160 & 729 \\
\hline K.B. & 0 & 0 & 0 & 320 & 0 & 0 & 240 & 729 \\
\hline M. B. (mother) & 0 & 160 & 40 & 320 & 0 & 2,187 & 0 & 59,049 \\
\hline F.B. (father) & 0 & 0 & 40 & 320 & 40 & 177,147 & 320 & 531,441 \\
\hline
\end{tabular}

Table IV. Polio neutralizing and complement fixing antibody titers before and after stimulation with poliovaccine

\begin{tabular}{|c|c|c|c|c|c|c|c|c|}
\hline \multirow{3}{*}{$\begin{array}{l}\text { Source of } \\
\text { serum }\end{array}$} & \multicolumn{6}{|c|}{ Reciprocal of neutralizing antibody titers } & \multirow{2}{*}{\multicolumn{2}{|c|}{$\begin{array}{l}\text { Reciprocal of } \\
\text { complement } \\
\text { Fixing antibody titers }\end{array}$}} \\
\hline & \multicolumn{2}{|c|}{ Type I } & \multicolumn{2}{|c|}{ Type II } & \multicolumn{2}{|c|}{ Type III } & & \\
\hline & Pre & Post & Pre & Post & Pre & Post & Pre & Post \\
\hline R.B. & $<8$ & 16 & 24 & 32 & 32 & 64 & $<8$ & $<8$ \\
\hline K. B. & 128 & 128 & 48 & 48 & 16 & 384 & $<8$ & $<8$ \\
\hline M.B. (mother) & 256 & 384 & 128 & 384 & 128 & 128 & $<8$ & $<8$ \\
\hline
\end{tabular}


Table $V$. Titers of antibodies to gamma globulin, thyroid and sheep cells in members of the family

\begin{tabular}{|c|c|c|c|c|c|}
\hline \multirow[t]{2}{*}{$\begin{array}{l}\text { Source of } \\
\text { serum }\end{array}$} & \multicolumn{5}{|c|}{$\begin{array}{c}\text { Reciprocal titers and specificities } \\
\text { of antibodies }\end{array}$} \\
\hline & $\mathrm{Gma}$ & $\mathrm{Gm} x$ & $\mathrm{Gm} \mathrm{c}$ & Thyroid & $\begin{array}{l}\text { Sheep } \\
\text { cells }\end{array}$ \\
\hline R.B. & 0 & 2 & 1 & 8 & 1 \\
\hline K. B. & 4 & 4 & 4 & 2 & 1 \\
\hline $\begin{array}{l}\text { M. B. } \\
\text { Mother }\end{array}$ & 0 & 0 & 0 & 4 & 32 \\
\hline
\end{tabular}

Table VI. Gm and Inv Types of the immediate family

\begin{tabular}{llllll}
\hline \multirow{2}{*}{$\begin{array}{l}\text { Source of } \\
\text { serum }\end{array}$} & \multicolumn{4}{c}{ Allotype characteristics } \\
\cline { 2 - 5 } & Gma & Gm x & Gm b & Gm c & Inv (1) \\
\hline G.B. & - & - & + & - & - \\
\hdashline K.B. & - & - & + & - & + \\
\hdashline R.B. & - & - & + & - & + \\
\hdashline M.B. & - & - & + & - & + \\
Mother & & & & & \\
\hdashline F.B. & - & - & + & - & - \\
Father & & & & & \\
\hline
\end{tabular}

history of conditions similar to those of the boys on either side of the family. A maternal first cousin had hay fever and asthma.

\section{Methods}

\section{Measurement of Immunoglobulins}

Immunoglobulins $\mathrm{G}, \mathrm{A}$ and $\mathrm{M}$ were quantitatively measured by a modification of Mancini's single radial diffusion method [46], using goat antisera specific for each of the human immunoglobulins and primary reference standards prepared in our laboratory. Details of the modification and reproducibility of the method, preparation of reagents and statistical analyses of normal data obtained from 201 individuals from infancy to adulthood are presented in another report [9]. Immunoglobulin measurements were usually performed within a week of collection of sera. The sera were stored at $-20^{\circ}$ and later simultaneously reanalyzed. Since the differences between the values obtained at the early and late analyses of a given serum sample did not exceed the limits of precision of the method $(< \pm 10 \%$ for each of the three immunoglobulins), the data presented are values obtained from the late analyses.

\section{Measurements of Circulating Antibodies}

Isohemagglutinins were measured by the tube dilution method [36a]. Titrations were performed in saline and in albumin. Antistreptolysin-0 [54a], Forssman

Table VII. Levels of immunoglobulins and isohemagglutinins in the nonimmediate family

\begin{tabular}{|c|c|c|c|c|c|}
\hline \multirow[t]{2}{*}{ Members } & \multirow[t]{2}{*}{$\operatorname{IgG}$} & \multirow{2}{*}{$\begin{array}{c}\operatorname{Ig} \mathrm{A} \\
\mathrm{mg} / 100 \mathrm{~m}\end{array}$} & \multirow[t]{2}{*}{$\operatorname{IgM}$} & \multicolumn{2}{|c|}{$\begin{array}{l}\text { Quantitative isohemaggluti- } \\
\text { nins (reciprocal of titers) }\end{array}$} \\
\hline & & & & \multirow{2}{*}{$\frac{\text { Anti-A }}{16^{1}}$} & \multirow{2}{*}{$\frac{\text { Anti-B }}{4^{1}}$} \\
\hline Maternal aunt & 1100 & 550 & 100 & & \\
\hline $\begin{array}{l}\text { Maternal first cousin } \\
\text { (9-year-old son of above aunt) }\end{array}$ & 880 & 490 & 86 & 128 & 64 \\
\hline Maternal aunt & 1100 & 440 & 80 & $32^{1}$ & $16^{1}$ \\
\hline $\begin{array}{l}\text { Maternal first cousin } \\
\text { (3-year-old son of preceding aunt) }\end{array}$ & 1060 & 135 & 47 & 128 & 64 \\
\hline $\begin{array}{l}\text { Paternal first cousin } \\
\text { (5-year-old male) }\end{array}$ & 820 & 224 & 35 & n.t. & n.t. \\
\hline $\begin{array}{l}\text { Paternal first cousin } \\
\text { (12-year-old brother of preceding }\end{array}$ & 1500 & 378 & 59 & n.t. & n.t. \\
\hline
\end{tabular}

Note: Geometric means and normal bounds for immunoglobulin levels in $\mathrm{mg} / 100 \mathrm{ml}$ in normal adults (this laboratory) are: IgG: 1061 (635-1775); IgA : 266 (106-668); IgM: 76 (37-154).

Normal reciprocal titers for anti-A are 64-512, for anti-B 32-256. n.t. = not tested.

1 Signifies abnormally low values. 
agglutinating, and typhoid ' $\mathrm{O}$ ' and ' $\mathrm{H}$ ' agglutinating antibodies were assayed by standard serological procedures [16a]. Diphtheria and tetanus antibodies were detected by Boyden's tanned cell hemagglutination procedure [6]. Thyroid antibodies were measured by the bis-diazotized benzidine hemagglutination method of Stavitsky and ArQuilla [63]. The Schick test was performed with a commercial antigen. Neutralizing antibodies to polioviruses were measured at the $\mathrm{Na}$ tional Communicable Disease Genter in Atlanta, Georgia $^{1}$, and polio complement-fixing antibodies were assayed by the North Carolina State Health Department ${ }^{2}$. Antibodies to gamma globulin were detected by hemagglutination of anti-D coated erythrocytes [28].

\section{Skin Tests}

Immediate hypersensitivity was tested by standard scratch and intradermal techniques, using commercial antigens ${ }^{3}$ or antigens prepared in the Allergy and Clinical Immunology Laboratory at Duke University Medical Center. Delayed hypersensitivity was assayed using a group of bacterial, viral and fungal antigens, one or more of which usually elicit responses in most normal individuals [11].

\section{Gm and Inv Typing}

Immunoglobulin allotypes in the family were determined using an hemagglutination-inhibition test employing erythrocytes coated with various anti-D reagents of known $\mathrm{Gm}$ and Inv types and utilizing known positive typing antisera $[28]^{4}$.

\section{Gamma Globulin Survival}

Gamma globulin fractions from R.B. and K.B., prepared from whole serum by ammonium sulfate fractionation at one-third saturation, were each labelled with ${ }^{131} \mathrm{I}$ by the iodine monochloride method of BALE et al. [3]; a commercial gamma globulin preparation ${ }^{5}$ was labelled with ${ }^{125} \mathrm{I}$ by the same method. Aliquots containing $50 \mu \mathrm{c}$ were injected intramuscularly. Plasma samples were counted at one- to three-day intervals over a 17-day period using a double channel liquid scintillation spectrometer.

${ }^{1}$ Paul M.Feorino, Ph.D., Entero Virus Unit, National Communicable Discase Center, Atlanta, Ga.

2 Norma Carrold, Serology Laboratory, North Carolina State Health Department, Raleigh, N.C.

${ }^{3}$ Hollister-Stier Laboratories, Spokane, Washington. ${ }^{4}$ These studies, as well as the measurements of antibodies to gamma globulin, were kindly performed by Dr. Anja TrrLIKainin of the Institute of Bacteriology and Serology, Helsinki, Finland.

${ }^{5}$ Lederle Laboratories, Pearl River, New York.
Phytohemagglutinin Stimulation of Lymphocytes

Peripheral lymphocytes were prepared from blood by sedimentation with Plasmagel, followed by passage of the white cell layers through nylon columns. The cells were cultured in the presence of phytohemagglutinin as described by HrRscH HORN [38], and the number of transformed cells per 100 cells examined was determined and expressed as a percent.

\section{Histocompatibility Testing}

Leukocyte typing studies were performed in the laboratory of Dr. D.B. Amos, using the lymphocyte cytotoxicity method [1] and employing a test panel of 23 antisera.

\section{Fluorescent Antibody Studies}

Aliquots of the same specific antisera used in the radial diffusion studies were chromatographed on DEAE cellulose and selected peaks were labelled with fluorescein isothiocyanate (FITC) $[13,71]$. Sections of lymph node $4 \mu$ in thickness were fixed in cold acetone, washed three times in phosphate-buffered saline, layered with the conjugated reagents and incubated at $37^{\circ}$ for 20 minutes. The slides were then washed in phosphate-buffered saline and examined under a Leitz Ortholux fluorescent microscope using a BG 12 exciter filter and a yellow barrier filter.

\section{Results}

\section{Serum Immunoglobulins}

Over a three-year period, levels of all three serum immunoglobulins in the father were normal (table I). Levels in a single serum sample from C. B. were compatible with a diagnosis of 'agammaglobulinemia' (table I and fig. 1). IgG levels in the mother remained within the normal range during a four-year period, but she consistently showed a marked elevation of $\operatorname{IgA}$ and low or low-normal levels of IgM (table I). The IgA concentrations were measured on two- and fourfold dilutions of her serum in order to increase the accuracy of the measurement. Electrophoresis of the mother's serum on cellulose acetate did not reveal a monoclonal spike or ' $M$ ' band, indicating the IgA hyperglobulinemia was polyclonal.

Serum levels of IgG in K.B. were below normal initially, but levels of $\operatorname{IgA}$ and $\operatorname{IgM}$ were normal. During the four-year period of study, the levels of IgG gradually declined and those of $\operatorname{IgM}$ decreased to values well below normal. The IgA levels declined but at all times were within the normal range (table $I$ and fig. 1). Thus his serum immunoglobulin abnormality selectively involved the IgG and IgM fractions. Salivary $\operatorname{IgA}$ measurement in $\mathrm{K}$. B. revealed a level of 


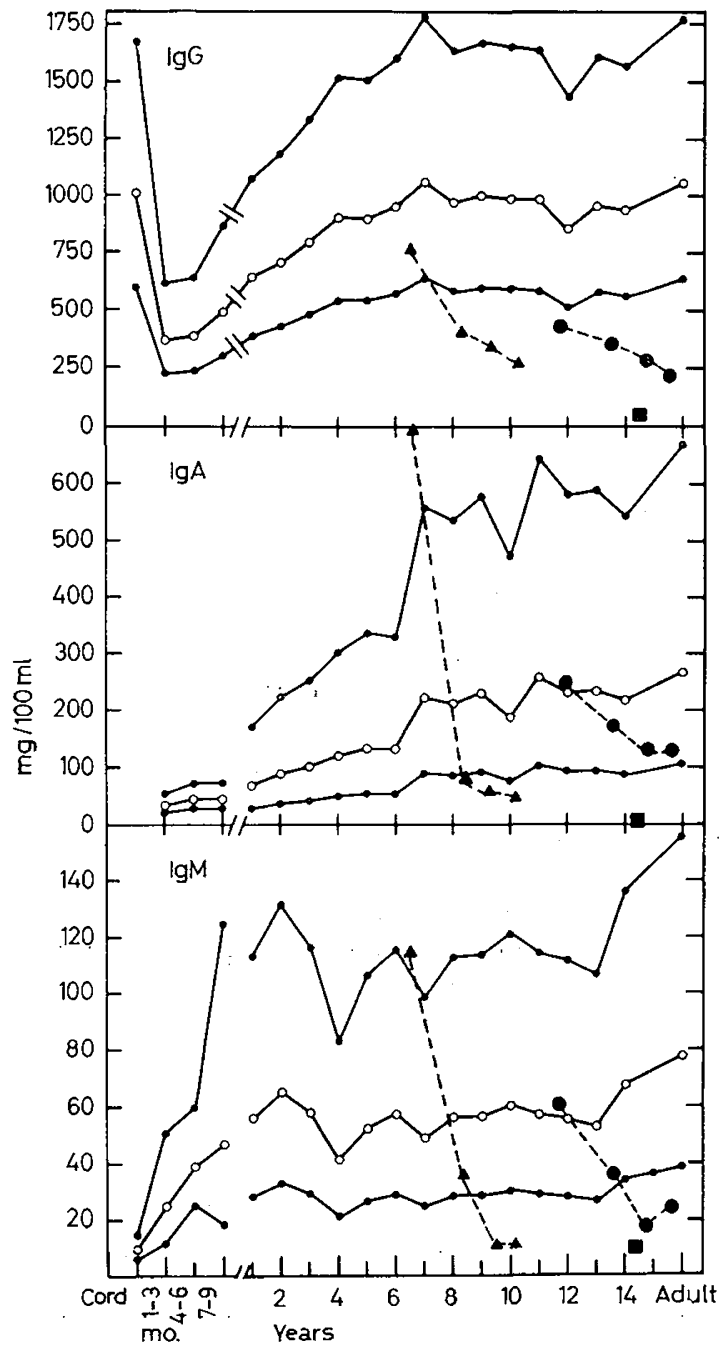

Fig.1. Open circles connected by solid lines represent geometric mean values for each immunoglobulin at each age in a group of 201 normal individuals from infancy to adulthood studied in this laboratory [9]. Closed circles connected by solid lines indicate the normal bounds which represent the antilogs of the mean logs $\pm 2 \mathrm{SD}$ of the logs. Sequential serum immunoglobulin measurements on R. B. are represented by the triangles, and: on K. B. by the large closed circles connected by broken lines. Values for a single serum analysis on C. B. are depicted by the large squares. A marked decline is evident in levels of all three immunoglobulins. in R. B. over the four-year period. IgG, IgA and IgM levels in K.B. gradually declined over this same period but at all times the IgA concentration was within the normal range. Very low concentrations of $\mathrm{IgG}$ and $\operatorname{IgM}$ were found in C. B. and $\operatorname{IgA}$ was absent.
$2 \mathrm{mg} / 100 \mathrm{ml}$. Normal values for salivary IgA are reported by other investigators to be $6 \mathrm{mg} / 100 \mathrm{ml} \pm 3$ $\mathrm{mg} / 100 \mathrm{ml} \mathrm{[36].}$

Initially in patient R.B., there was a normal level of IgG and elevated levels of the IgA and IgM fractions. There was a striking diminution in the concentrations of all three immunoglobulin fractions over the four-year period of study, so that ultimately his serum abnormality resembled that seen in the state of acquired hypogammaglobulinemia (table I and fig. 1).

The blood type of all immediate family members was 0 , Rh positive (table II). No antibodies to 'B' cells were found in any serum samples of R. B., either prior to or after specific stimulation ${ }^{6}$. Patient R. B. failed to show a rise in anti-A titer after stimulation. Anti-A and anti-B titers in K. B. were both 32 and remained so following stimulation. The mother had a normal antiA titer, 64, prior to stimulation and responded normally to stimulation with A substance $[64,65]$; however, her anti-B titer was abnormally low, 4 , prior to stimulation and 8 following stimulation with $B$ substance $[64,65]$. All titration results obtained using saline as a diluent were within one tube of the titer obtained when albumin was used as the diluent. Anti-A and anti-B titers were normal in the father prior to stimulation and rose normally following it (see table II).

Both boys and the mother were immunized with $0.1 \mathrm{ml}$ of typhoid-parathypoid vaccine by three intracutaneous injections given two weeks apart. Two weeks after the last injection there were no detectable anti-

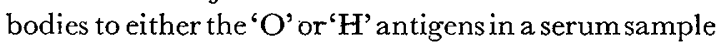
obtained from R.B. (table III). K.B. did develop agglutinins against the ' $\mathrm{H}$ ' antigen but none against the ' $\mathrm{O}$ ' antigen, while the mother developed significant increases in antibodies against both antigens. The father, previously immunized, responded normally to a single injection of $0.1 \mathrm{ml}$ of typhoid-parathyphoid vaccine and developed antibodies only to the ' $\mathrm{H}$ ' antigen. A low titer of antidiphtheria antibodies was found in the serum of R.B. prior to stimulation, but only a slight rise was noted afterward; K. B. had no detectable antibodies to this antigen before or after stimulation. Schick tests were, nevertheless, negative in both boys, but K. B. was still receiving exogenous gamma globulin when the test was performed. 'Booster' injections of diphtheria vaccine resulted in a normal rise in titer of antidiphtheria antibodies in the father and a significant, though abnormally low, rise in the mother [16]. All four members of the family responded to tetanus 'booster' injections with a rise in antibody titer, but

${ }^{6}$ Patients received a single intramuscular injection of $0.5 \mathrm{ml}$ of A and B Blood Group Concentrate (Merck, Sharpe and Dohme, Philadelphia) and were tested 14 days later. 
the titers in the two boys were lower than those seen in normal individuals following similar injections [16].

Neutralizing antibody titers in the two younger boys and their mother to polio Types I, II and III, before and after 'booster' stimulation with trivalent oral poliovaccine, are shown in table IV. R. B. showed a slight but probably insignificant rise in titers of antipolio Types I and II antibodies, but not to Type III; K.B. responded significantly only to Type III; and the mother responded with a slight but probably insignificant rise in titers of antipolio. Types I and II antibodies, but did not respond to Type III. Reciprocal titers of complement-fixing antibodies were less than 8 both before and after stimulation with Salk vaccine in all three individuals.

In view of the lack of obvious improvement in the clinical condition of the two younger boys while receiving gamma globulin therapy, their sera were tested for the presence of isoantibodies to IgG (table V). R.B. had low titers to $\mathrm{Gm} x$ and $\mathrm{Gm}$ c factors; and K.B. had somewhat higher titers against $\mathrm{Gm}$ a, $\mathrm{Gm}$ x, and $\mathrm{Gm}$ c. The mother had no detectable antibodies to gamma globulin. The specificities of the isoantibodies produced in the boys correlated well with the absence of those allotypes on their own gamma globulins (table VI).

To determine the presence of antithyroid 'autoantibodies', a hemagglutination test was performed [63]. These were present in the two younger boys and in their mother in low titers (table V). They were:absent in the father. Abnormally low levels of heterophile antibodies were found in the two boys. Antistreptolysin-O titers were less than 100 in the boys and in their mother.

Skin Tests

Immediate type skin reactions to a large group of pollen, food, inhalent and miscellaneous antigens, including Ascaris antigen, performed by scratch and intradermal methods, were all negative in the two younger boys and in their mother. Delayed hypersensitivity was tested in the two younger boys and in their mother. K. B. had $3+$ to $4+$ reactions (15. to $>20$ mm of erythema and induration) to 4 of 6 antigens; R.B. had a 2 reaction ( 1.0 to $15 \mathrm{~mm}$ ) to 3 of 6 antigens, and the mother had a 2 + reaction ( 10 to $15 \mathrm{~mm}$ ) to 4 of 6 antigens. Thus, delayed hypersensitivity mechanisms appeared to be functioning in all three individuals.

\section{Gamma Globulin Survival}

The studies of autologous and homologous gamma globulin survival in the two boys and in the mother showed over a period of 17 days similar and parallel slowly declining levels of gamma globulin from both sources, with no evidence of immune elimination of the homologous protein [72].

\section{Gamma Globulin Allotypes}

The results of $\mathrm{Gm}$ and Inv typing of family members are presented in table VI. All members were Gm b positive. The father was. Inv (1) negative, but the mother and two younger boys were Inv (I) positive. The very low immunoglobulin level of $C$. B. could account for the lack of detectable Inv (1) factor in his serum; therefore, a true absence of this factor cannot be concluded. The gamma globulin allotypes of two patients resembled that of the mother and the allotype of one patient resembled that of the father.

\section{Histocompatibility Testing}

Gytotoxicity testing, with a panel of 23 typing antisera, showed that in comparison with the findings in the mother, the lymphocytes of each boy reacted with one more typing antiserum. Beyond that, the mother's cells reacted in a pattern identical with that of the boys. Conversely, three antisera in the panel which reacted with the father's cells failed to react with cells from the mother and boys, and each boy's cells reacted with two antisera which failed to react with the father's cells. Thus, the histocompatibility-typing studies indicated a closer resemblance : of the boys' tissue antigens to those of the mother than to those of the father.

\section{Phytohemagglutinin Stimulation of Lymphocytes}

Peripheral lymphocytes from the two younger boys, cultured in the presence of phytohemagglutinin, showed 95 percent transformation to blast-likè cells in each case. These responses are comparable to those seen in normal individuals and are very different from the response of lymphocytes taken from individuals with impaired cellular immunity. In the latter instance, transformation is minimal in the presence of phytohemagglutinin $[40,58]$.'

\section{Bone Marrow Cytology}

Examination of bone marrow aspirates taken from the two younger boys failed to reveal any plasma cells among 500 cells counted. The histology was normal otherwise except for a moderate increase in segmented neutrophils.

\section{Fluorescence Microscopy}

Unfixed, frozen, hilar nodes obtained at surgery from $\mathrm{K}$. B. were sectioned and examined for the presence of immunoglobulin-containing cells. A moderate number of cells appearing to belong to the plasma cell series was detected with each specific antiserum $(\mathrm{G}$, A and $\mathrm{M}$ ), but proportionately more cells were seen with the FITC-conjugated anti-IgA than with the two other reagents. When the number of stained cells in sections from K.B.'s node was compared with the number of stained cells in sections of hilar lymph node 
from a young adult dying from vascular anomaly, there were greater numbers of cells detected with all three reagents in the latter case, but proportionally more cells reacted with the FITC anti-IgG.

\section{Other Family Studies}

Immunoglobulin levels and isohemagglutinin titers were determined in nonimmediate family members who were available for study (table VII). No immunoglobulin deficiency was detected in any of the members, but it is pertinent that IgA levels were in the upper range of normal in two maternal aunts and in the son of one of the aunts. These same two maternal aunts had low titers for both anti-A and anti-B. The cousin with the high normal IgA had asthma, shortness of stature and suffered from recurrent respiratory infections.

\section{Discussion}

The members of this family present many unusual features of immunologic deficiency both in the variable clinical manifestations and in the heterogeneity of the immunoglobulin abnormalities detected. It is surprising that an entire sibship should be affected, particularly with the absence of a positive family history for immunologic deficiency. Published reports of familial hypogammaglobulinemia have emphasized similarity in the clinical and immunologic findings of affected members of the same family [19, 23, 42, 43]. There have been no reports of acquired hypogammaglobulinemia in the same sibship with cases of congenital 'agammaglobulinemia'.

The deficiency of the oldest boy best fits the clinical descriptions of congenital 'agammaglobulinemia' [8, $31,34]$, since repeated infections began in infancy, the total and fractional immunoglobulin levels found were in the range generally described as characteristic for this entity [62], and a serum electrophoretic analysis at seven years of age revealed low or absent gamma globulins. In addition, the marked growth retardation and extent of lung disease noted when he was first seen by us indicated that his illness was chronic. The potential role of pertussis in early infancy in accelerating and accentuating the immunologic deficiency in this boy cannot be evaluated, but recurrent infections followed that illness. Histopathological findings in his tonsils and adenoids removed at six years of age unfortunately were not available. Pharyngeal lymphoid tissue is usually minimal in the X-linked type of 'agammaglobulinemia' [51]. As in the present study, thestructure of the thymus gland has almost without exception been normal in the congenital form of 'agammaglobulinemia' in which affected individuals survive beyond infancy [51].
In contrast, the history of frequent infections in the second boy did not begin until he was about ten years of age. It is pertinent that the history of recurrent infection began prior to detectable alterations in gamma globulin concentrations. Recurrent pneumonia began at the age of ten years, but at the age of eleven years, gamma globulin levels measured by paper strip electrophoresis were reported as normal, and at the age of $11 \frac{1}{2}$ years, the total immunoglobulin level was 735 $\mathrm{mg} / 100 \mathrm{ml}$, a level well above that seen in the defined immunologic deficiency syndromes. Nevertheless, at this time he was found to have abnormalities in specific antibody response. By the age of fifteen years, his total immunoglobulins had decreased to $372 \mathrm{mg} / 100 \mathrm{ml}$, and levels of IgG and IgM were well below the normal range suggesting, as in the case of the youngest boy, an acquired immunologic abnormality. Unlike his younger brother, his tonsils were of normal size. Of the seven possible immunoglobulin deficiency phenotypes, considering only IgG, IgA and IgM, the only type heretofore undescribed is one in which $\mathrm{IgG}$ and IgM are decreased but IgA is normal [30]. This phenotype is exemplified by the findings in this boy and in several other children subject to recurrent infection who are reported in a study to be published [10]. As in 'agammaglobulinemia' and hypogammaglobulinemia, repeated infection is a feature in all types of selective immunoglobulin deficiency. Some individuals with isolated IgA deficiency who reportedly did not have this propensity have been described [56] but this has not been true in our experience.

The third boy also had a late onset of repeated infections which were primarily upper respiratory. When he was first seen at the age of $6 \frac{1}{2}$ years, his total immunoglobulin level was $1564 \mathrm{mg} / 100 \mathrm{ml}$. Nevertheless, at that time he was already subject to recurrent infection, he had absent ' $\mathrm{B}$ ' and low ' $\mathrm{A}$ ' isohemagglutinins, and the tonsils were vestigial. Thus, as in the second boy, propensity to infection and specific immunologic unresponsiveness preceded gross abnormalities in the immunoglobulin levels. During the four-year period of study, there was a marked diminution in all three immunoglobulin fractions, so his immunoglobulin deficiency syndrome best fits that of primary acquired hypogammaglobulinemia. In primary acquired hypogammaglobulinemia, repeated infections associated with low gamma globulins usually begin between 15 and 35 years of age $[27,31]$, but a number of examples have been reported in children under 15 years of age $[12,14,20,31,55]$. The splenic enlargement noted in this boy is not unique: it has been observed in several other instances of hypogammaglobulinemia [15, 18, $50,57]$.

In spite of a history of hay fever in the mother and in the two younger boys, all skin tests evaluating imme- 
diate hypersensitivity were negative. In contrast, markedly positive immediate reactions were noted in testing the male cousin who had a high-normal level of IgA, recurrent upper and lower respiratory infections, asthma and shortness of stature. This cousin and his mother resemble somewhat the mother and son reported by HuntLey et al. [41], who had IgA hyperglobulinemia, with the son also having asthma and shortness of stature. The association of allergic disorder with diseases of immunologic aberrations has been noted by several investigators $[32,33,35,48,52]$. IgE was detected in the serum of a child with an unusual dysgammaglobulinemia, reaginic antibody and a family history for allergy [33] but this serum protein was not examined in our patients. The normal delayed hypersensitivity reactions found in the patients in this study have been noted in many cases of congenital X-linked recessive 'agammaglobulinemia' [54].

The findings of particular interest in this family are the familial deficiency of an antibody response to specific antigens, with near normal or elevated levels of immunoglobulins. Unresponsiveness to specific antigens has been noted in human immunologic deficiency syndromes in which levels of one or more immunoglobulins are normal, such as the Aldrich syndrome $[17,49,68]$, the Giedion and Scheidegger abnormality [29], ataxia telangiectasia [59], and the syndrome of BARTH et al. [4]. Abnormally low virus antibody titers have been found in individuals subject to infections but having normal or elevated levels of immunoglobulins [45]. In vitro phytohemagglutinin stimulation of peripheral blood lymphocytes from some of the mothers of boys with congenital 'agammaglobulinemia' have produced two cell populations (demonstrated by immunofluorescence), only one of which contained immunoglobulins [39]. Specific immunologic unresponsiveness or antibody deficiency of the type found in the mother and maternal aunts in the present study have not been reported in mothers of boys with congenital 'agammaglobulinemia'.

The deficiency in the ability to form specific antibodies would appear to be heritable as an X-linked characteristic in this family. Although the serum immunoglobulin abnormalities in the mother and in the three boys were dissimilar, the inheritance appears to be X-linked. The high-normal levels of $\operatorname{IgA}$ and low isohemagglutinins in the maternal aunts provide additional support for an X-linked mode of inheritance for both the antibody deficiency and the abnormal immunoglobulin levels in this family. One of these aunts has a son who also has a high-normal level of IgA, recurrent upper and lower respiratory tract infections, asthma and shortness of stature. The phenotypic similarity of the immunoglobulin allotypes of two of the boys and their mother indicates that these char- acteristics were also inherited from the mother. Since it appears that the Inv locus is on an autosome, however, it is doubtful that inheritance of this factor from the mother is related to the inheritance of the deficiency states [27].

It has been suggested that mutation of a gene regulating light chain synthesis could explain the general depression of immunoglobulin synthesis in congenital 'agammaglobulinemia' [27]. A mutation of regulator genes controlling synthesis of one of the types of heavy chains has been proposed as an explanation for the selective deficiencies involving only one immunoglobulin [27], but this would not appear applicable in those selective deficiency states where more than one immunoglobulin is deficient. A mechanism involving defective 'read-off' of the structural genes for $\gamma$ and $\alpha$ polypeptide chain synthesis has been invoked in Type I dysgammaglobulinemia and in the selective deficiency state of BARTH et al. [4], since close linkage has been demonstrated between genes controlling synthesis of these two heavy chains in mice $[37,44]$. A maturation arrest in the development of the lymphoid system has been proposed by others who postulate that the genetic defect in immunologic deficiency may be a lack of an enzyme or of a mesenchymal inducer necessary for full lymphoid system maturation [51].

It is difficult to conceive of a way in which any of the above mechanisms could be operative in the family described in the present report, since the affected members have phenotypically different immunoglobulin alterations and the siblings have varying lymphoid structural development. Any mechanism proposed must explain: (1) an inability to produce certain specific antibodies prior to gross quantitative deficiencies in immunoglobulins; and (2) a delayed progressive decline in serum immunoglobulin concentrations in two of the members. Specific immunologic unresponsiveness has been studied in animals [5, 53, 60], and this trait could be selected by proper matings [60]. It has been suggested that the failure to produce antibodies could be due to a failure to break down antigen or to an abnormality in the postulated recognition system at the level prior to synthesis of immunoglobulins [53]. Lymphocytes from some patients with 'agammaglobulinemia' appear capable of undergoing morphologic transformation when stimulated by PHA in vitro [16, $26,27]$ but they synthesize less gamma globulin than do normal lymphocytes $[2,24,27,38]$ as well as less DNA and RNA [65]. Possible reasons proposed for this defective response include a lack of cellular replication in response to antigen or a metabolic defect in the lymphocytes [24, 65]. The cause of the increased severity of the defects with time is not apparent. It is possible that environmental influences may interact with genetic mechanisms to produce the disease states 
observed. Lymphoid hypoplasia and depressed capacity to form antibody have been induced in neonatal mice by repeated injections of sterile vaccines prepared from a variety of gram-positive and gram-negative bacteria [21, 22]. We can only speculate about the possible roles of repeated bacterial infections, with resultant steady release of bacterial constituents such as endotoxin, in contributing to the progressiveness and heterogeneity of the immunologic deficiencies noted in this sibship. The detection of low to absent antibodies to ' $B$ ' substance in a number of members of this family prior to immunoglobulin deficiency could be related to the undue susceptibility to infection, since it is known that a large number of bacteria have polysaccharide cell wall antigens which have antigenic determinants identical with those of the A, B, 0 blood group mucoids [61]. A genetically controlled afferent phase or recognition defect, together with secondarily induced immunologic impairment, possibly by bacterial substances or other environmental agents, could account for the variable types of immunologic abnormality seen in this family.

\section{Summary}

A family is described in which an entire sibship of three brothers is affected with three different types of immunologic deficiency syndromes: 'agammaglobulinemia', acquired hypogammaglobulinemia and a selective immunoglobulin deficiency in which IgG and $\operatorname{lgM}$ are deficient. In addition, the mother of these boys was found to have a marked polyclonal IgA hyperglobulinemia and defects in specific immunologic responsiveness. These findings provide direct evidence of genetic influence in at least some forms of acquired immunologic deficiency as well as in congenital 'agammaglobulinemia'. An afferent phase defect is felt to offer the best explanation for a single genetic mechanism of immunologic deficiency in this family.

\section{References and Notes}

1. Amos, D. B.: Some results on the cytotoxicity test. Histocompatibility testing, p.151 (Munksgaard, Copenhagen 1965).

2. BACH, F. and HirschHorn, K. $: \gamma$-globulin production by human lymphocytes in vitro. Exp. Cell Res. 32: 592 (1963).

3. Bale, W. F.; Helmkamp, R.W.; Davis, T.P.; Izzo, M.Z.; Goodland, R.L. and Spar, I.L.: Atomic Energy Commission Research and Development Report UR-604 (University of Rochester, New York 1962).
4. BARth, W.F.; Asofsky, R.; Liddy, F.J.; TAnaka, Y.; Rowe, D. S. and FAHEY, J. L.: An antibody deficiency syndrome. Selective immunoglobulin deficiency with reduced synthesis of $\gamma$ and $\alpha$ immunoglobulin polypeptide chains. Amer.J. Med. 39: 319 (1965).

5. Benacerraf, B.; Ojeda, A. and Maurer, P.H.: Studies on artificial antigens. II. The antigenicity in guinea pigs of arsanilic acid conjugates of copolymers of D or L-alpha-amino acids. J. exp. Med. 118: 945 (1963).

6. Boyden, S.V.: The adsorption of proteins on erythrocytes treated with tannic acid and subsequent hemagglutination by antiprotein sera. J. exp. Med. 93: 107 (1951).

7. BROOKE, M.S.: Experimental runt disease in mice caused by Salmonella typhimurium var. Copenhagen, J.exp. Med. 120: 375 (1964).

8. Bruton, O.C.: Agammaglobulinemia. Pediatrics 9: 722 (1952).

9. Bugkley, R.H. and Dees, S. C.: Serum immunoglobulins: I. Levels in normal children and in uncomplicated childhood allergy. Pediatrics (To be published, March, 1968).

10. Buckley, R.H. and Dees, S. C.: Serum immunoglobulins: II. Levels in children subject to recurrent infection. Pediatrics (To be published, 1968).

11. Buckley, R.H. and Dees, S. G.: Serum immunoglobulins: III.Abnormalities associated with chronic urticaria in children. J. Allergy 40: 294 (1967).

12. Burtin, P.; Buffe, D. et Grabar, P.: Les hypogammaglobulinémies $(x)$ atypiques. Ann. Inst. Pasteur 106: 519 (1964).

13. Cerbra, J.J. and Goldstein, G.: Chromatographic purification of tetramethylrhodamine-immune globulin conjugates and their use in the cellular localization of rabbit gamma globulin polypeptide chains. J. Immunol. 95: 230 (1965).

14. Charache, P.; Rosen, F.S.; Janeway, C.A.; Craig, J.M. and Rosenberg, H.A.: Acquired agammaglobulinemia in siblings. Lancet $i: 234$ (1965).

15. Grtron, K. M.: Agammaglobulinemia with splenomegaly. Brit.med.J. $i$ : 1148 (1957).

16. Grine, M.J. and Fudenberg, H.H. : Defective RNA synthesis in lymphocytes from patients with primary agammaglobulinemia. Science 150: 1311 (1965).

16a. Clinical diagnosis by laboratory methods, 13th ed. (ed. Davidsohn, I. and Wells, B. B.) (Saunders, Philadelphia, $\mathrm{Pa}$. 1962).

17. Cooper, M.D.; Ghase, P.; St.Geme, J.W., Jr.; Krivit, W. and Good, R.A.: Wiskott-Aldrich syndrome: Model of impaired defense mechanism. J. Lab. clin. Med. 64: 849 (1964). 
Hereditary alterations in the immune response: Coexistence of 'agammaglobulinemia'...

18. Davis, S. D.; Ching, Y. C.; Schaller, J.; SchurtLEFF, D.B.; Hecht, F. and WedGeWOOD, R.J.: The congenital agammaglobulinemias. Amer.J. Dis. Child. 113: 186 (1967).

19. Diamant, M.; Kallós, P. and Rubensohn, G.: Familial agammaglobulinemia. Int. Arch. Allergy 19: 193 (1961).

20. Ersen, A.H.; Beaudry, P.H.; David, M. and BACAL, H.L.: 'Acquired' hypogammaglobulinemia. Canad.med. Ass. J. 94: 498 (1966).

21. Ekstedt, R. D. and Hayes, L.L.: Runt disease induced by non-living bacterial antigens. J. Immunol. 98: 110 (1967).

22. Ekstedt, R.D. and Nishimura, E.T.: Runt disease induced in neonatal mice by sterile bacterial vaccines. J. exp. Med. 120: 795 (1964).

23. Elphinstone, R.H.; Wicker, I. G. and Anderson, A. B.: Familial agammaglobulinemia. Brit.med.J. ii: 336 (1956).

24. Forbes, I.J. and Milazzo, S.C.: A metabolic defect of the lymphocytes in a case of hypogammaglobulinemia. Austr. Ann. Med. 14: 311 (1965).

25. Fudenberg, H.; German, J. L., III, and Kunkel, H. G.: Occurrence of rheumatoid factor and other abnormalities in families of patients with agammaglobulinemia. Arthr. and Rheum. 5: 565 (1962).

26. FudenberG, H.H. and HirschHorn, K. : Agammaglobulinemia: The fundamental defect. Science 145: 611 (1964).

27. Fudenberg, H.H. and Hrrschhorn, K. : Agammaglobulinemia: Some current concepts. Med. Clin. N.Amer. 49: 1533 (1965).

28. Fudenberg, H.H. and Kunkel, H. G.: Specificity of the reaction between rheumatoid factors and gamma globulin. J. exp. Med. 114: 257 (1961).

29. Gredion, A. von und Scheidegger, J.J.: Kongenitale Immunparese bei Fehlen spezifischen $\beta_{2}$-Globulins und quantitativ normalem $\gamma$-Globulin. Helv. paediat. Acta 12: 241 (1957).

30. Gituin, D.: Current aspects of the structure, function, and genetics of the immunoglobulins. Annual review of medicine, vol.17, pp.1-22 (Annual Reviews, Palo Alto 1966).

31. Grturn, D.; Janeway, C.A.; Apt, L. and Craig, J.M.: Agammaglobulinemia; in Cellular and humoral aspects of the hypersensitive states (ed. LAWrence, H.S.) (Hoeber, New York 1959).

32. Goldfarb, A.A. and Fudengerg, H.H.: Hypogammaglobulinemia and its relationship to the allergic diathesis. N.Y.J. Med. 61: 2721 (1961).

33. Goldman, A.S.; Haggard, M.E.; MaFadden, J.; Ritzman, S.; Houston, E.W.; Bratcher, R.L.; Weiss, K. G. ; Box, E. M. and Szekrenyes, J.W.: Thymic alymphoplasia, lymphoma, and dysglobulinemia. Hyper-gamma-A, normo-gamma-M,
hypo-gamma-G, a-gamma-D, and gamma $\mathrm{E}$ globulinemia, plasmacytosis, normal delayed hypersensitivity, severe allergic reactions, and Coombs positive anemia. Pediatrics 39: 348 (1967).

34. Good, R.A.; Kelly, W.D.; Rötstein, J. and VARCO, R. L.: Immunological deficiency diseases. Progr. Allergy 6: 187 (1962).

35. Goodman, D.H.: Hypogammaglobulinemia with respiratory allergy. J. Allergy 31: 298 (1960).

36. Haworth, J. G. and Dilling, L.: Concentrations of $\gamma$ A-globulin in serum, saliva, and nasopharyngeal secretions of infants and children. J. Lab. clin. Med. 67: 922 (1966).

36a. Hepler, O.E.: Manual of clinical laboratory methods, 4th ed., p. 245 (Thomas, Springfield, Ill. 1958).

37. Herzenberg, L.A.: A chromosome region for gamma-2 and beta-2A globulin $\mathrm{H}$ chains in the mouse. Cold Spr. Harb. Symp.quant. Biol. 24: 455 (1964).

38. HirschHoRN, K.; BACH, F.; KolODNY, R.L.; Firschein, I.L.; and Hashem, N.: Immune response and mitosis of human peripheral blood lymphocytes in vitro. Science 142: 1185 (1963).

39. Hirschmorn, K. and Firschein, I.L: Genetic activity of the $\mathrm{x}$-chromosome in man. Trans. N.Y. Acad. Sci. 26: 545 (1964).

40. Hitzig, W.H.; KAy, H.E.M. and Cottier, H.: Familial lymphopenia with agammaglobulinemia. ('Swiss type of agammaglobulinemia') : attempt of treatment by implantation of foetal thymus. Lancet ii: 151 (1965).

41. Huntcey, G. C.; Johnson, H.W. and Lyerly, A.D.: Asthma, short stature and elevated $\gamma_{1}$ A globulins. Amer. J. Dis. Child. 109: 353 (1965).

42. Jamieson, W.M. and KerR, M.R.: A family with several cases of hypogammaglobulinemia. Arch. Dis. Childh. 37: 330 (1962).

43. Kushner, D.S.; Dubin, A.; Donlon, W.P. and BRonsky, D.; Familial hypogammaglobulinemia, splenomegaly, and leukopenia. Amer.J. Med. 29: 33 (1960).

44. Leiberman, R. and Potrer, M.: Close linkage in genes controlling gamma $\mathrm{A}$ and gamma $\mathrm{G}$ heavy chain structure in BALB/c mice. J. Molec. Biol. 18: 516 (1966).

45. Lo Grippo, G.A.; Wolfram, B.R. and Hayashi, H.: Serum globulin dyscrasia: Lack of virus neutralizing antibodies in normal serum and in hypergammaglobulinemia. J.amer. med. Ass. 191: 109 (1965).

46. Mancint, G.; Carbonara, A.D. and Heremans, J.F.: Immunochemical quantitation of antigens by single radial immunodiffusion. Immunochemistry 2: 235 (1965). 
47. Morse, S. I.: Studies on lymphocytosis induced in miceby Bordetella pertussis. J.exp.Med.121:49(1965).

48. Painter, T.S. and Korset, D. R.: Studies on acquired hypogammaglobulinemia. Evidence of antibody formation and report of a case with bronchial asthma. New Engl.J. Med. 260: 15 (1959).

49. Palmgren, B. and Lindberg, T.: Immunological studies in Wiskott-Aldrich syndrome. Acta Paediat. Suppl. 146: 116 (1963).

50. Pearce, K. M. and Perinpanayagam, M. S.: Congenital idiopathic hypogammaglobulinemia. Arch. Dis. Childh. 32: 422 (1957).

51. Peterson, R.D.A.; Cooper, M.D. and Good, R.A.: The pathogenesis of immunologic deficiency diseases. Amer.J. Med. 38: 579 (1965).

52. Peterson, R.D.A.; Page, A.R. and Good, R.A.: Wheal and erythema allergy in patients with agammaglobulinemia. J. Allergy 33: 406 (1962).

53. Pinchuck, P. and Maurer, P.H.: Antigenicity of polypeptides (poly alpha amino acids). SVI Genetic control of immunogenicity of synthetic polypeptides in mice. J. exp. Med. 122: 673 (1965).

54. PoRTER, H. M. : Immunologic studies in congenital agammaglobulinemia, with emphasis on delayed hypersensitivity. Pediatrics 20: 958 (1957).

54 a. RANTz, L.A. and Randalt, E.: Modification of techniques for determination of the antistreptolysin titre. Proc. Soc. exp. Biol. (N.Y.) 59: 22 (1945).

55. Robbins, J. B.; Ertzman, D.V. and Ellis, E.: Immunochemical evidence for the development of an 'acquired' hypogammaglobulinemic state. New Engl.J. Med. 274: 607 (1966).

56. Rocky, J. H.; Hanson, L. A.; Heremans, J. F. and KUNKEL, H. G. : $\beta_{2}$ A aglobulinemia in two healthy men. J. Lab. clin. Med. 63: 205 (1964).

57. Rohn, R.J.; Belinke, R.H. and Bend, W.H.: Acquired agammaglobulinemia with hypersplenism: case report. Amer. J. med. Sci. 229: 406 (1955).

58. Rosen, F.S.; Gotoff, S.P.; CRAIG, J. M.; Rutchie, J. and JANEWAY, C. A.: Further observations of the Swiss type of agammaglobulinemia (a-lymphocytosis). The effect of syngeneic bone marrow cells. New Engl.J. Med. 274: 18 (1966).

59. Shuster, J.; Hart, Z.; Stimson, G.W.; Brough, A.J. and Poulrk, M. D. : Ataxia telangiectasia with cerebellar tumor. Pediatrics 37: 776 (1966).

60. Sobey, W.R.; Magrath, J.M. and Reisner, A. H.: Genetically controlled specific immunological unresponsiveness. Immunology 11: 511 (1966).

61. Springer, G.F.; Williamson, P. and Brandes, W. C. : Blood group activity of gram-negative bacteria. J. exp. Med. 113: 1077 (1961).

62. SQuire, J.R.: Hypogammaglobulinemia in Great Britain. Proc. 7th Congr. europ. Soc. Haemat., London 1959; Acta heamat. (Basel) 24: 99 (1960).
63. Stavitsky, A.B. and Arquilla, E. R.: Studies of proteins and antibodies by specific hemagglutination and hemolysis of protein-conjugated erythrocytes. Int. Arch. Allergy 13: 1 (1958).

64. Thomsen, O. and Ketrel, K.: The titers of human isoagglutinins and corresponding red cell receptors at different ages. Z. Immun.-Forsch. 63: 67 (1929).

65. Tormey, D. C. ; Kamin, R. and FudenberG, H. H. : Quantitative studies of phytohemagglutinin-induced DNA and RNA synthesis in normal and agammaglobulinemic leukocytes. J. exp. Med. 125: 863 (1967).

66. Witebsky, E.; KlendshoJ, N. G. and MaNeil, G.: Potent typing sera produced by treatment of donors with isolated blood group specific substances. Proc. Soc. exp. Biol. N.Y. 55: 167 (1944).

67. WoLF, J.K.: Primary acquired agammaglobulinemia with a family history of collagen disease and hematologic disorders. New Engl.J. Med. 266: 473 (1962).

68. WolfF, J. A.: Wiskott-Aldrich syndrome: Clinical, immunologic, and pathologic observations. J. Pediat. 70: 221 (1967).

69. Wollheim, F.A.; Belfrage, S.; Coster, G. and Lindholm, H.: Primary 'acquired' hypogammaglobulinemia, clinical and genetic aspects of nine cases. Acta med. scand. 176: 1 (1964).

70. Wollherm, F.A. and Williams, R. G.: Immunoglobulin studies in six kindreds of patients with adult hypogammaglobulinemia. J. Lab. clin. Med. 66: 433 (1965).

71. Wood, B.T.; Trompson, S.H. and Goldstein, G.: Fluorescent antibody staining. III. Preparation of fluoroscein-isothiocyanate-labeled antibodies. J. Immunol. 95: 225 (1965).

72. Dixon, F.G. and Jalmage, D.W.: Catabolism of $I^{131}$ labelled bovine gamma globulin in immune and non-immune rabbits. Proc.Soc.exp.Biol. (N.Y.) 78: 123 (1951).

73. The authors express their appreciation to Dr. D.B. Amos who performed the lymphocyte cytotoxicity tests, to Dr. Anja Tillikainen for the Gm typing, and to Dr. E.D. DAy who radiolabelled the gamma globulin fractions for the survival studies.

74. These studies were supported in part by General Glinical Research Genter Grant (MO 1 Fr 30) from the National Institutes of Health, and by research grants from the Duke University Council on Research, the North Carolina Tuberculosis Association, and the National Institutes of Health.

75. Requests for reprints should be addressed to: Dr. RebecaA H. Buckley, Department of Pediatrics, Duke University Medical Center, Durham, N. C. 27706 (USA). 